\title{
What Do Pennsylvania Voters Think about Gender and Women's Representation?
}

\author{
What We Learned from 2016 and 2018 Exit Polls
}

\section{SARAH NIEBLER}

Dickinson College

\section{A. LANETHEA MATHEWS-SCHULTZ}

Muhlenberg College

Despite ongoing interest in the role of gender in American elections, highlighted most recently by Hillary Clinton's historic bid for the presidency in 2016 and the 2018 "Year of the Woman" elections, recent studies have shown that gender alone is not enough to explain voter behavior. This is especially true in an increasingly ideologically polarized landscape in which party and ideology retain significant explanatory power regarding electoral outcomes. The saliency of gender identity and gender issues may also vary across time and context. Moreover, voters may not have full information about the underrepresentation of women or of the consequences of gender imbalances in elective institutions, raising uncertainty about whether women's representation in politics matters to voters. In this article, using data from a unique exit poll, we examine the extent to which knowledge about women's representation and perceptions about gender and women's issues mattered to Pennsylvanians' vote choice in the 2016 and 2018 elections. We find that neither gender nor party alone can explain men's and women's political behavior, but rather that gender and party interact in complex ways. Although party continues to be the best predictor of vote choice, gender matters to how voters understand and explain women's underrepresentation in politics - a finding that has important implications for furthering gender equality in politics in the future. 
W hile Hillary Clinton's historic presidential run in 2016 reignited scholarly interest in the role of women in American politics, Donald Trump's unanticipated victory (following a campaign marked by misogyny and boasts about sexually harassing women) may have done more to catalyze activism among women seeking a voice in the political arena. The Women's March on January 21, 2017, was the largest coordinated protest in U.S. history and one of the largest in world history (Meyer and Tarrow 2018; Berry and Chenoweth 2018). The newfound sense of solidarity among women evident in the Women's March was further fueled by the \#MeToo movement later that year; both are at least partially responsible for the emergence of the 2018 Year of the Woman elections in which a record number of women ran for and won elective office. The 2018 Year of the Woman shares with 1992the first Year of the Woman in which record numbers of women entered the U.S. Congress - a context marked by eerily similar high-profile hearings into alleged sexual misconduct on the part of Supreme Court nominees.

The confluence of these events in 2016 and 2018 drew collective attention to the underrepresentation of women and to potential links between gender, women's issues, and party. Clinton, for example, centered her identity as a mother and grandmother within a campaign strategy that made frequent references to families and children, and described herself as a woman embarking on a historic campaign to become the first female president of the United States (Chozick and Martin 2015; Nichols 2017). Anti-Trump narratives were common and not limited to Democrats in 2018, as would be expected during any midterm election from the party not in power. These messages were especially prominent among female Democratic candidates, of whom more than half centered their campaigns around women's issues including reproductive health and the end of sexual harassment and gender violence (often directly referencing \#MeToo and the Kavanaugh hearings). News stories about female candidates - covering women as women-dominated print and social media throughout the campaigns, leading one Republican strategist to anticipate "a female revolution" at the voting booth (Kapur and McCormick 2018). Voters echoed this sentiment in national exit polls on Election Day with more than $50 \%$ saying that electing women to office is important and that sexual harassment is a serious problem facing our nation (CNN 2018).

Despite the fact that gender was a prominent frame in political discourse in 2016 and 2018, past research suggests that it might not have made much of a difference to voters' perceptions or to their votes. Hayes and Lawless (2016) show, for example, that despite the persistence of notions that gender matters to elections (manifest as sexism on the campaign trail or in voters' gender bias toward candidates), candidates, campaigns, and voters generally divide along 
the lines of party. Vote choice and perceptions of candidates and their campaigns are shaped more by long-standing partisan attachments than by any kind of gender affinity. At first glance, exit poll data seems to confirm the significance of party. While Trump's unexpected victory was born of some crossparty voting by Democratic voters in key states (including Pennsylvania), 89\% of Democrats voted for Clinton on Election Day while 88\% of Republicans voted for Trump; this is compared to 2012 when $92 \%$ of Democratic voters voted for Obama and 93\% of Republican voters voted for Romney (CNN 2012; CNN 2016). In the 2018 midterm elections, $95 \%$ of Democrats voted for a Democratic House candidate; $94 \%$ of Republicans voted for a Republican House candidate.

In this article we examine questions about the relationship between party identification and gender and how those two variables affect voters' party identification, vote choices, positions on gender-related issues, and their understanding and knowledge about women's underrepresentation in electoral politics in the United States. Specifically, we ask: Did gender transcend party in 2016 and 2018? Did voters consider the historic nature of Clinton's candidacy? How did Trump's rhetoric about women shape political behavior in 2016? How did the Year of the Woman elections in 2018 affect voters' perceptions about the political arena, women's representation, and the significance of gender-related issues?

Drawing on data from unique exit polls conducted in 2016 and 2018 in three Pennsylvania counties (Allegheny, Cumberland, and Lehigh), we find that gender impacted voters' party identification and vote choice, but in different ways between the two years. We also find some evidence for a genderaffinity effect as Republican women were more likely to support Hillary Clinton in 2016 than would have been expected considering only party or gender. Additionally, we find that neither gender nor party alone is enough to explain how women (and men) understand women's underrepresentation in politics or how they viewed the political significance of Trump's behavior toward women or the 2018 Year of the Woman. Rather, gender and party interact in complex ways. In particular, partisan identification, not gender identity, seems to best explain how Pennsylvania voters considered Trump's comments about women and the Kavanaugh nomination, and partisanship also shapes how voters explain women's underrepresentation in office. This finding lends support to the notion that voters, both men and women, evaluate candidates primarily through the lens of party. Gender does have an independent effect, however, when it comes to how men and women interpret the \#MeToo movement and how they understand explanations for women's underrepresentation in politics. Even taking into account political party identification, female 
voters were more likely than male voters to suggest that overt sexism and lack of party support are responsible for women's underrepresentation.

\section{Linking the Gender Gap to Women's Representation}

Among the most notable empirical trends in studies of gender and political behavior is the gender gap in party and voting; that is, women are more likely than men to align with the Democratic party and to vote for Democratic candidates as compared to their male counterparts. The gender gap was very much apparent in 2016 and 2018. Women supported Clinton over Trump $54 \%$ to $42 \%$ - at $12 \%$, it is the largest presidential gender gap in voting since 1996 (the average gender gap between 1980 and 2016 was only 8\%) (Tyson and Maniam 2016). Among men Clinton received the lowest support of any Democratic candidate since 1992, gaining only $41 \%$ of their votes (Presidential Gender Watch 2017). In 2018 59\% of women voted for the Democratic House candidate; in the 2014 midterm elections, this figure was only 51\%. Men split their votes more evenly among Democrats and Republicans in 2018: 47\% of men voted for a House Democrat compared to $51 \%$ who voted for a House Republican.

If persistent, the gender gap is quickly complicated upon deeper analysis. Frasure-Yokley (2018) points out, for example, that the gender gap obscures important differences and sources of heterogeneity in perceptions and attitudes among women (see also Cassese and Barnes 2019). Particularly relevant, with few exceptions (including 1992 and 1996), white women have consistently supported Republican presidential candidates. More than one-half of white women supported Trump in 2016, suggesting that the gender gap in 2016 was driven by race and gender. While only $43 \%$ of white women voted for Clinton, $94 \%$ of black women did; among men, $82 \%$ of black men voted for Clinton, compared to $31 \%$ of white men (Philpot 2018).

This is not to suggest that gender is irrelevant to politics, but rather that its explanatory power does not result from a simple "gender-affinity effect." Rather, gender is best understood in interaction with other factors, especially party and gender stereotypes. For example, gender stereotypes matter to the ways that voters evaluate candidates and think about issues. Sanbonmatsu (2002) uses gender schema theory to show that many voters are predisposed to support female over male candidates (or vice versa) and that this preference can affect voters' decisions at the polls. Specifically, Sanbonmatsu finds that women are more likely than men to have a baseline preference for female candidates. For similar reasons gender stereotypes may shape the ways that voters 
infer candidates' ideological orientations (Koch 2000). Especially important is the extent to which partisanship provides cues to help organize voters' perceptions of candidates and their understanding and prioritization of issues. Democrats and Republicans hold different stereotypes about men and women, especially when it comes to candidates' and officeholders' issue competencies, leading to differential effects of gender within party (Sanbonmatsu and Dolan 2009). Women, regardless of party identification, are more supportive of an activist government, for example, and more likely to favor more liberal policy positions on a range of issues including the use of force, social policy, and the environment, and they are more likely to rank these issues differently in terms of salience when compared to men (Lizotte 2014; Ondercin 2017). Voters may not always agree with their party on every issue and there may be important differences between men and women on issue positions within their party (Lizotte 2014).

Whether or not gender gaps in perceptions, candidate evaluation, and issue positions hurt or help particular kinds of candidates is unclear. Overt sexism does not appear to directly shape voters' choices (Hayes and Lawless 2016). ${ }^{1}$ Some research suggests that gender-based stereotypes may reduce the ideological distance between Republican female candidates and voters; other research suggests that voters' gender stereotypes put Republican female candidates at a disadvantage (Sanbonmatsu and Dolan 2009; Hayes 2011; see also King and Matland 2003). Brians (2005) finds that Republican female voters are more willing to cross party lines to vote for female candidates, but that Democratic female voters are reluctant to do the same. Other studies find no consistent pattern between gender stereotypes and vote choice given the strength of party (Dolan 2014; Hayes and Lawless 2016). This is especially the case in an increasingly polarized political environment with record high levels of party voting among lawmakers and increased partisanship among the engaged public (Abramowitz 2012). Media coverage of national elections sharpens partisan cues, and candidate campaigns orient their messages and issue agendas to reinforce partisanship. In turn, the impact of partisanship on the public's evaluation of candidates has grown to its highest level in decades (Jacobson 2006).

In this kind of electoral environment, Ondercin (2017) argues, the gender gap is a consequence of voters' shifting partisanship in ways that are directly tied to gendered social identities. Given that voters select the party that best represents their social identities, Ondercin suggests, party realignments and shifts in the composition of men and women in elective office send signals to voters about which party best represents them. One of the most notable shifts 
is the increasing numbers of women who have been elected to office in the Democratic party (and a corresponding decrease in the numbers of women elected in the Republican party). The gender gap, then, is a consequence of changes in men's and women's macropartisanship in response to the gender makeup of congressional delegations and to the symbolic images of each party.

Previous research suggests that in 1992, the first Year of the Woman, gender was more relevant to political behavior than it had been in previous, and possibly subsequent, elections (K. Dolan 2004; Sanbonmatsu 2003). Sanbonmatsu (2003) argues, for example, that the Anita Hill testimony during the Clarence Thomas hearings in 1991 suggested a link between the descriptive and substantive representation of women, providing an issue context favorable for female candidates and heightening voters' sense of urgency in increasing women's presence in Congress. Historic numbers of female candidates in the 1992 congressional elections-when gender issues were particularly salient, female candidates were exceptionally competitive running as women, and the media devoted significant time to covering both-were linked to increased political involvement among women (Campbell and Wolbrecht 2006; K. Dolan 1998, 2004; Sapiro and Conover 1997; see also Koch 1997) and to increased support for electing women to office (Sanbonmatsu 2003).

Kathleen Dolan's research $(1998,2004)$ notably shows that gender matters to the extent that female voters prefer female candidates and are more likely to consider gender-related issues when voting compared to men. But electoral environment is key: gender matters in certain kinds of information environments in which gender-related issues are especially salient. Similarly, although they argue the declining novelty of women as candidates coupled with increased partisan polarization makes sex and gender largely irrelevant to elections, Hayes and Lawless concede that in some circumstances, such as when "charges of sexism arise" or "when campaigns are explicitly gendered," gender "can work its way into a campaign" $(2016,9)$. It is in these cases, they suggest, that gender becomes relevant, newsworthy, and linked to election outcomes. Put differently, rather than asking does gender matter?, past research suggests a more appropriate question is when does gender matter? This article examines the extent to which gender was especially salient in 2016 and 2018 in interaction with, and potentially in ways that transcended, political party in shaping voters' perceptions and explanation of women's underrepresentation, their attitudes toward gender-related issues, and their voting decisions on Election Day. 


\section{Research Design and Methods}

On Election Day 2016, students from Dickinson and Muhlenberg Colleges conducted exit polls in Cumberland and Lehigh Counties. In 2018 Dickinson and Muhlenberg were joined by students from Chatham University and the University of Pittsburgh who administered exit polls in Allegheny County. Like most exit polls, the questionnaires in 2016 and 2018 contained questions about vote choice, policy positions, and demographics. Particularly relevant to this article were questions about salient gender and women's issues. In 2016, we asked voters whether treatment of women is a legitimate campaign issue; we also asked voters about their perceptions of Trump's comments on the Access Hollywood tape. In 2018, we asked voters about their views of the \#MeToo movement and the nomination of Brett Kavanaugh to the U.S. Supreme Court. Additionally, in 2018 we asked respondents to estimate the percentage of women in both the U.S. Congress and the Pennsylvania state legislature since Sanbonmatsu (2003) finds that knowledge about women's representation is related to support for electing women to office. Following Dolan and Hansen (2018) we also asked 2016 and 2018 voters whether they explained women's underrepresentation as a consequence of voter bias, individual variables (such as family status or career path), or systemic-level variables (including insufficient support from political parties and political elites). ${ }^{2}$

Our Pennsylvania exit polls are not meant to represent all Pennsylvania voters (and certainly not all voters nationally). Rather, these exit polls allow us to examine relationships among multiple variables. In other words, while we would not want to make any claims about how many Democrats and Republicans are actually in Lehigh and Cumberland Counties (in 2016 and 2018) and Allegheny County (in 2018) using just exit poll data, we are confident in our ability to talk about relationships among variables. For instance, our data allow us to understand how gender and party may interact to affect vote choice, and they provide insight into voters' perceptions of the causes for women's underrepresentation in the American political system.

In 2016, student pollsters talked to 482 voters in Cumberland County and 252 voters in Lehigh County, for a total of 734 voters overall. In 2018, a total of 1,307 participants responded to the survey-481 from Allegheny County, 455 from Cumberland County, and 371 from Lehigh County. In both years of the survey, because our students talked to a disproportionate number of people who voted for Democrats, we weighted the exit poll data. In 2016, we weighted to the presidential vote totals in each county and in 2018 we weighted to the Senate vote totals in each county. ${ }^{3}$ 


\section{Results}

We first examine the relationship between gender and party identification since research has identified a significant gender gap in men's and women's propensity to identify with the two major political parties. We also include race of respondent since we know that non-white voters are more likely than white voters to identify as Democrats than as Republicans. Table 1 illustrates these results. In the 2016 exit poll, 34\% of our total respondents identified as Democrats, $48 \%$ as Republicans, and $18 \%$ as Independents. When we break this down by gender and race, we see that both non-white women and nonwhite men are more likely to identify with the Democratic Party than their white counterparts. Of non-white women respondents, 55\% indicated they were Democrats while just $37 \%$ of white women said the same (chi-square $=$ $5.312, p=.07)$. Of non-white men, $60 \%$ said they were Democrats while just $24 \%$ of white men replied in the same way (chi-square $=24.503, p<.001$ ). When we look at the gender gap within racial groups, we find evidence for a gender gap between men and women, but only among white respondents (chi-square $=13.515, p=.001$ ).

Compared to the 2016 exit poll, the 2018 exit poll had a larger percentage of Democratic respondents. This is due, in part, to our addition of Allegheny County (containing the city of Pittsburgh) to the survey, but even within Cumberland and Lehigh Counties, the percentage of Democratic respondents increased between 2016 and 2018. Table 2 shows the relationship between party identification, gender, and race among our 2018 exit poll respondents. There are no statistically significant differences between women and men, nor between white and non-white respondents with respect to party identification in this non-representative sample. The counties in which we surveyed (with

\begin{tabular}{|l|l|l|l|l|l|}
\hline \multicolumn{2}{|c|}{ Table 1. Party Identification of Exit Poll Respondents in 2016, by Race and Gender } \\
\hline 2016 & $\begin{array}{l}\text { All } \\
\text { Respondents }\end{array}$ & $\begin{array}{l}\text { White } \\
\text { Wemen } \\
\text { Respondents }\end{array}$ & $\begin{array}{l}\text { White Men } \\
\text { Respondents }\end{array}$ & $\begin{array}{l}\text { Non-white } \\
\text { Women } \\
\text { Respondents }\end{array}$ & $\begin{array}{l}\text { Non-white } \\
\text { Men } \\
\text { Respondents }\end{array}$ \\
\hline Democrats & $34 \%$ & $37 \%^{\dagger}$ & $24 \%^{*^{\dagger}}$ & $55 \%^{\dagger}$ & $60 \%^{\dagger}$ \\
\hline Republicans & $48 \%$ & $45 \%^{\dagger}$ & $57 \%^{{ }^{\dagger}}$ & $29 \%^{\dagger}$ & $23 \%^{\dagger}$ \\
\hline $\begin{array}{l}\text { Unaffiliated } \\
\text { or Third-Party }\end{array}$ & $18 \%$ & $18 \%$ & $19 \%$ & $17 \%$ & $18 \%$ \\
\hline \multicolumn{7}{|l|}{ Total } & $\begin{array}{l}100 \% \\
(N=682)\end{array}$ & $\begin{array}{l}100 \% \\
(N=328)\end{array}$ & $\begin{array}{l}100 \% \\
(N=272)\end{array}$ & $\begin{array}{l}101 \% \\
(N=42)\end{array}$ & $\begin{array}{l}101 \% \\
(N=40)\end{array}$ \\
\hline${ }^{*}$ Gender difference (within race) is statistically significant $(p<.10)$. \\
${ }^{\dagger}$ Racial difference (within gender) is statistically significant $(p<.10)$.
\end{tabular}




\begin{tabular}{|c|l|l|l|l|l|}
\hline \multicolumn{2}{|c|}{ Table 2. Party Identification of Exit Poll Respondents in 2018, by Race and Gender } \\
\hline & All & $\begin{array}{l}\text { White } \\
\text { Women } \\
\text { Respondents }\end{array}$ & $\begin{array}{l}\text { White Men } \\
\text { Respondents }\end{array}$ & $\begin{array}{l}\text { Non-white } \\
\text { Women } \\
\text { Respondents }\end{array}$ & $\begin{array}{l}\text { Non-white } \\
\text { Men } \\
\text { Respondents }\end{array}$ \\
\hline Democrats & $66 \%$ & $65 \%$ & $66 \%$ & $68 \%$ & $68 \%$ \\
\hline Republicans & $23 \%$ & $22 \%$ & $24 \%$ & $23 \%$ & $23 \%$ \\
\hline $\begin{array}{l}\text { Unaffiliated } \\
\text { or Third-Party }\end{array}$ & $12 \%$ & $14 \%$ & $11 \%$ & $10 \%$ & $10 \%$ \\
\hline Total & $\begin{array}{l}101 \% \\
(N=1,119)\end{array}$ & $\begin{array}{l}101 \% \\
(N=508)\end{array}$ & $\begin{array}{l}101 \% \\
(N=395)\end{array}$ & $\begin{array}{l}101 \% \\
(N=132)\end{array}$ & $\begin{array}{l}101 \% \\
(N=84)\end{array}$ \\
\hline
\end{tabular}

Note: There are no gender differences (within race) and no racial differences (within gender) that are statistically significant $(p<.10)$.

the exception of Cumberland County) are more Democratic than the state as a whole. Further, in 2018, possibly due to an "enthusiasm gap" between Democratic and Republican voters, especially in mostly white suburban districts (Cohn 2018), Democrats were more likely to talk with our student pollsters than were Republican voters in the precincts we surveyed. Especially in 2018, white Democrats were more likely to talk with our students than were white Republican voters.

We next examine the relationship among party identification, race, and gender and vote choice of our exit poll respondents in 2016 and 2018. Given the nature of American politics, we expect that party identification will have a significant effect on vote choice across the board. We also include gender, race, age, and education as controls in our models. ${ }^{4}$ Our key variable of interest in this analysis, however, is a binary variable for GOP women (coded 1 if respondent was both a Republican and a woman). If large numbers of Republican women broke with their party and voted for Hillary Clinton in 2016, that could provide some evidence of a gender-affinity effect. In 2018, both the Democratic and Republican Senate candidates were men (Bob Casey-D and Lou Barletta-R), so if Republican women broke with their party to support Casey, that may point to the increased saliency of women's issues, \#MeToo, the Women's March, and heightened campaign and media attention to gender. With respect to U.S. House races, in 2016 all exit poll respondents were in U.S. House districts that were contested only by men in the general election. In 2018, exit poll respondents living in Lehigh County were in District 7 in which Susan Wild (D) competed against Marty Nothstein (R). All other 2018 exit poll respondents were in House districts in which two men competed against one another. Thus we analyze vote choice in the 2018 U.S. House elections in Lehigh County separately from the other two counties. 
is a woman and not when the candidate is a man (all Democratic U.S. House candidates in 2016). As indicated earlier, this provides some evidence for a gender-affinity effect. ${ }^{5}$

The results of the 2018 elections, also presented in Table 3, show more complicated results. Despite the polarized nature of American politics, party identification is not consistently significant across all vote choice results. In 2018 Republicans reported voting for Democrats at much higher rates than they did in 2016. ${ }^{6}$ Additionally, while it is true that Casey's support across the state was higher than Clinton's in 2016 (55.7\% to 47.6\%), upwards of 70\% of all our respondents indicated they voted for Casey. We think this could be due, at least in part, to the enthusiasm gap and the proclivity of people who vote for Democrats to respond to exit polls, especially those administered by college students. Looking at the remainder of the results for the 2018 elections, we see that gender and race both have statistically significant effects across both the Senate and House elections. Women were more likely than men to vote for Democratic candidates as were non-white voters compared to white voters. We do not see any evidence for a gender-affinity effect in 2018 as neither women overall, nor Republican women, were more likely to support the Democrat in Lehigh County (where the Democratic candidate was a woman) than in Allegheny and Cumberland Counties (where all the Democratic candidates in the U.S. House races were men).

Our next set of analyses considers the degree to which women and men, and Democrats and Republicans, viewed the issues surrounding the 2016 and 2018 campaigns differently. In 2016, we included questions on the exit poll centered on the comments Trump made about women in the Access Hollywood tape; in 2018, questions focused on the \#MeToo movement and the nomination of Justice Brett Kavanaugh to the U.S. Supreme Court. Figure 1 illustrates the effects of gender and partisanship on the 2016 questions while Figure 2 shows the same bivariate effects for the 2018 questions. In both figures, the effect of party identification appears to dwarf any effect based on gender of the respondent, with Democrats in 2016 being more likely than Republicans to say that how candidates treat women is a legitimate campaign issue and that Trump's Access Hollywood comments affected their decision about whom to vote for in the presidential election. Republicans were more likely than Democrats to label the Access Hollywood comments as "typical locker-room talk by men." In 2018, Democrats were more likely than Republicans to both have a favorable view of the \#MeToo movement overall and say that it had a positive impact on them personally. Republicans were much more likely than were Democrats, however, to support the nomination of Brett Kavanaugh to the United States Supreme Court. 


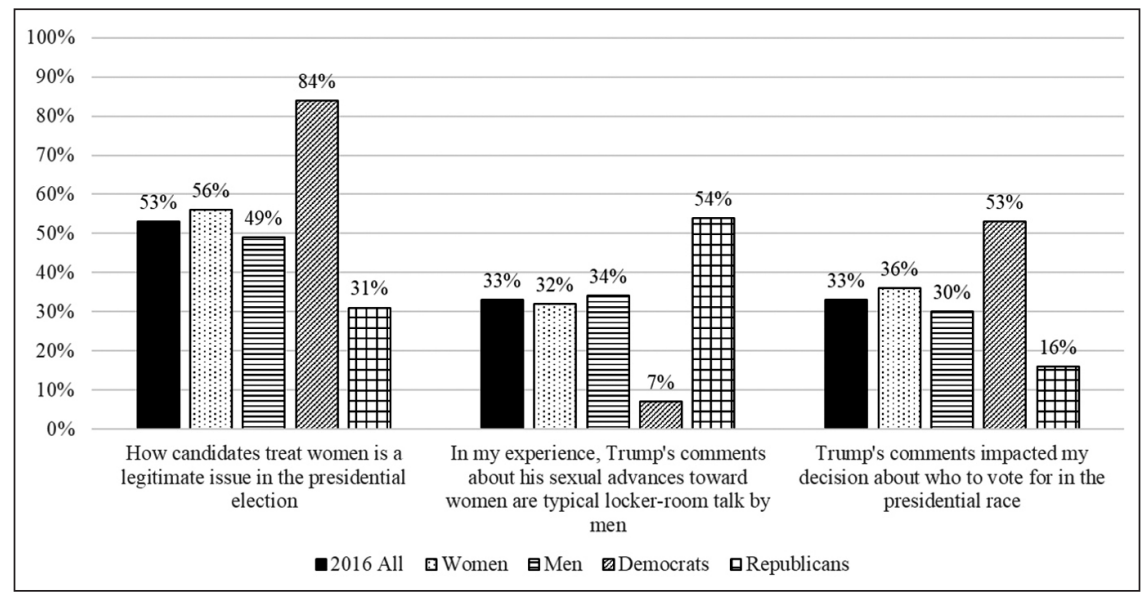

Figure 1. Effect of Gender and Partisanship on Candidates' Treatment of Women and Access Hollywood Tape Comments. (Source: Authors.)

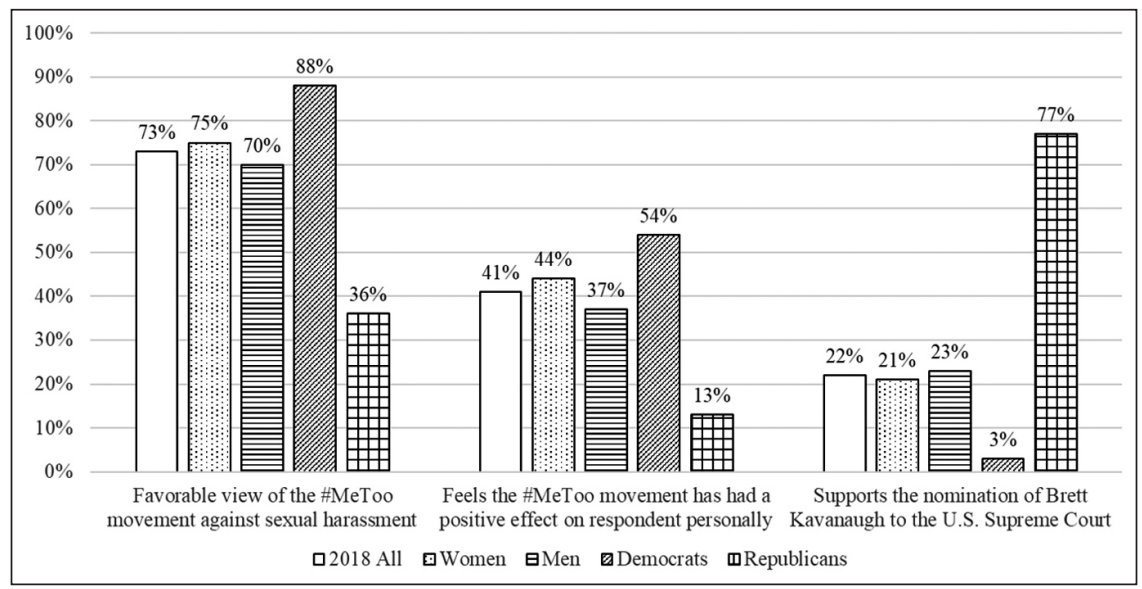

Figure 2. Effect of Gender and Partisanship on \#MeToo Movement and Kavanaugh's Nomination to the U.S. Supreme Court. (Source: Authors.)

Table 4 shows the results of multivariate analyses examining the impact of party identification and gender on the above questions, while also controlling for age and race. The effect of party identification was confirmed by the multivariate models, but beyond party identification, gender was significant in the two models dealing with questions about the \#MeToo movement. In both instances, women were more likely than men to say that they had a more favorable view of the \#MeToo movement and that it affected them positively on a personal level. 


\begin{tabular}{|c|c|c|c|c|c|c|}
\hline & $\begin{array}{l}\text { Legitimate } \\
\text { Issue }\end{array}$ & $\begin{array}{l}\text { Locker-Room } \\
\text { Talk }\end{array}$ & $\begin{array}{l}\text { Comments } \\
\text { Impacted } \\
\text { Vote }\end{array}$ & $\begin{array}{l}\text { Favorable } \\
\text { View of } \\
\text { \#MeToo }\end{array}$ & $\begin{array}{l}\text { Positive } \\
\text { Personal } \\
\text { Effect of } \\
\text { \#MeToo }\end{array}$ & $\begin{array}{l}\text { Support } \\
\text { Kavanaugh } \\
\text { Nomination }\end{array}$ \\
\hline Party ID & $\begin{array}{l}-1.175^{* * *} \\
(0.106)\end{array}$ & $\begin{array}{l}1.316^{* * *} \\
(0.127)\end{array}$ & $\begin{array}{l}-0.858^{* * *} \\
(0.101)\end{array}$ & $\begin{array}{l}-1.344^{* * *} \\
(0.092)\end{array}$ & $\begin{array}{l}-1.083^{* * *} \\
(0.101)\end{array}$ & $\begin{array}{l}2.385^{* * *} \\
(0.136)\end{array}$ \\
\hline Female & $\begin{array}{c}0.159 \\
(0.178)\end{array}$ & $\begin{array}{c}0.129 \\
(0.187)\end{array}$ & $\begin{array}{c}0.035 \\
(0.180)\end{array}$ & $\begin{array}{c}0.349 * \\
(0.160)\end{array}$ & $\begin{array}{c}0.309 * \\
(0.134)\end{array}$ & $\begin{array}{l}-0.167 \\
(0.222)\end{array}$ \\
\hline Age & $\begin{array}{c}-0.009 \\
(0.093)\end{array}$ & $\begin{array}{c}-0.002 \\
(0.098)\end{array}$ & $\begin{array}{c}-0.025 \\
(0.093)\end{array}$ & $\begin{array}{c}0.015 \\
(0.073)\end{array}$ & $\begin{array}{c}0.028 \\
(0.060)\end{array}$ & $\begin{array}{l}0.391^{* * *} \\
(0.101)\end{array}$ \\
\hline White & $\begin{array}{c}0.095 \\
(0.281)\end{array}$ & $\begin{array}{c}0.263 \\
(0.329)\end{array}$ & $\begin{array}{l}-0.153 \\
(0.260)\end{array}$ & $\begin{array}{l}-0.157 \\
(0.208)\end{array}$ & $\begin{array}{l}-0.072 \\
(0.167)\end{array}$ & $\begin{array}{c}0.658^{*} \\
(0.291)\end{array}$ \\
\hline Constant & $\begin{array}{l}2.532 * * * \\
(0.392)\end{array}$ & $\begin{array}{l}-4.049 * * * \\
(0.489)\end{array}$ & $\begin{array}{l}1.212^{* *} \\
(0.364)\end{array}$ & $\begin{array}{l}3.212^{* * *} \\
(0.293)\end{array}$ & $\begin{array}{l}1.036^{* * *} \\
(0.241)\end{array}$ & $\begin{array}{l}-7.277^{* * *} \\
(0.517)\end{array}$ \\
\hline$R^{2}$ & 0.169 & 0.180 & 0.100 & 0.210 & 0.108 & 0.512 \\
\hline$N$ & 665 & 664 & 664 & 1,085 & 1,094 & 1,102 \\
\hline \multicolumn{7}{|c|}{$\begin{array}{l}\text { Dependent variable is binary, coded } 1 \text { if respondent answered affirmatively to the question. } \\
\text { Logistic regression coefficients are provided, with standard deviations in parentheses. } \\
{ }^{*} p<.05 ;{ }^{* *} p<.01 ;{ }^{* *} p<.001\end{array}$} \\
\hline
\end{tabular}

Next, before we consider voters' views of why women are underrepresented in electoral politics, we want to examine whether individuals actually know the extent to which women are underrepresented, especially in Pennsylvania's U.S. House delegation. As mentioned earlier, prior to 2018 Pennsylvania's congressional delegation included no women. On the 2018 exit poll, we asked voters to indicate "how many of Pennsylvania's 18 House of Representatives members" are women. Of the 1,034 respondents who provided an answer to the question, just $84(8 \%)$ provided the correct response. Table 5 considers the extent to which party identification and gender explain a voter's correct or incorrect response to this question, while again controlling for age, education, and race. As shown, respondents' party identification was significant while gender was not. Republicans were less likely than Democrats to know that zero members of Pennsylvania's congressional delegation were women-a reflection, perhaps, of the centrality of women's representation to campaigns in 2018, nearly all of which were Democratic campaigns. ${ }^{7}$

We find party to be significantly related to voters' knowledge about women's underrepresentation, but we are also curious as to how it and gender affect how voters explain women's underrepresentation. Our exit polls in both 2016 


\begin{tabular}{|c|c|}
\hline Party Identification & $\begin{array}{l}-0.572^{* *} \\
(0.175)\end{array}$ \\
\hline Women & $\begin{array}{c}-0.246 \\
(0.231)\end{array}$ \\
\hline Education & $\begin{array}{c}0.094 \\
(0.119)\end{array}$ \\
\hline Age & $\begin{array}{l}0.378^{* * *} \\
(0.108)\end{array}$ \\
\hline White & $\begin{array}{c}-0.088 \\
(0.285)\end{array}$ \\
\hline Constant & $\begin{array}{l}-2.594^{* * *} \\
(0.595)\end{array}$ \\
\hline$R^{2}$ & 0.044 \\
\hline $\mathrm{N}$ & 975 \\
\hline \multicolumn{2}{|c|}{$\begin{array}{l}\text { Dependent variable is binary, coded } 1 \text { if respondent answered the question correctly. } \\
\text { Logistic regression coefficients are provided, with standard deviations in parentheses. } \\
{ }^{*} p<.05 ;{ }^{* *} p<.01 ;{ }^{* *} p<.001\end{array}$} \\
\hline
\end{tabular}

and 2018 included a series of questions measuring respondents' perceptions about women's underrepresentation, allowing us to examine these relationships. We asked voters to select from the following six reasons that might explain women's low levels of representation:

- Women are held to higher standards than are men.

- Many Americans aren't ready to elect a woman to higher office.

- Women who are active in politics get less support from party leaders.

- Few women have the experience to run for office.

- Family responsibilities don't leave time for politics.

- Women aren't tough enough for politics.

Figures 3 and 4 illustrate the overall percentage of respondents who selected each reason and also breaks down the responses by gender and party identification. In general, reasons summarized in Figure 3 can be understood as system-level causes; those included in Figure 4 are more individual-level causes. Just as with the analyses above, it appears as though party 


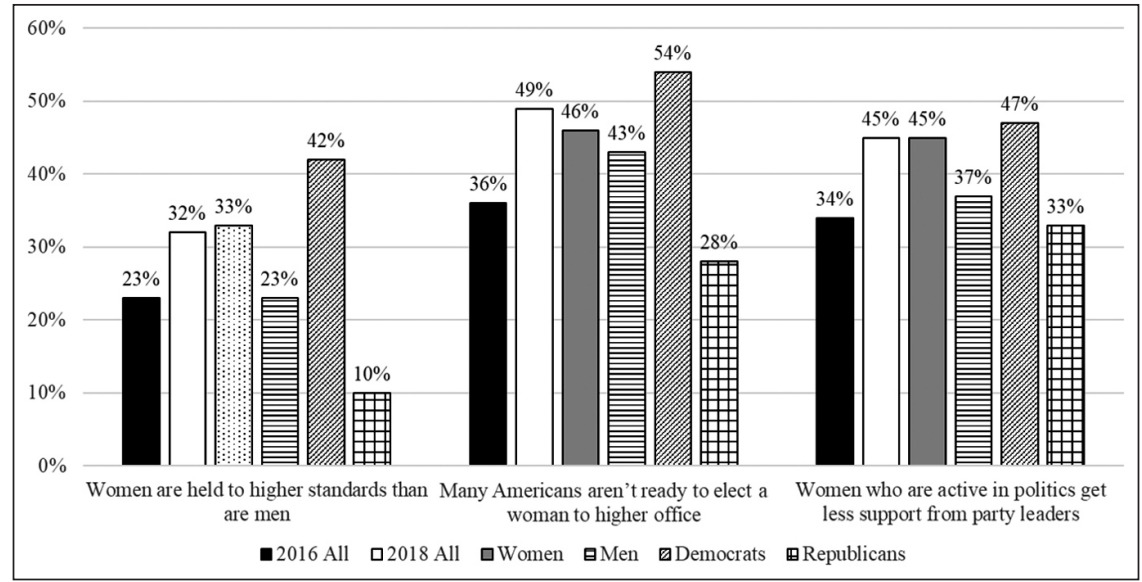

Figure 3. Reasons Why More Women Do Not Hold Elected Office in the United States Overall, and by Gender and Party Identification. (Source: Authors.)

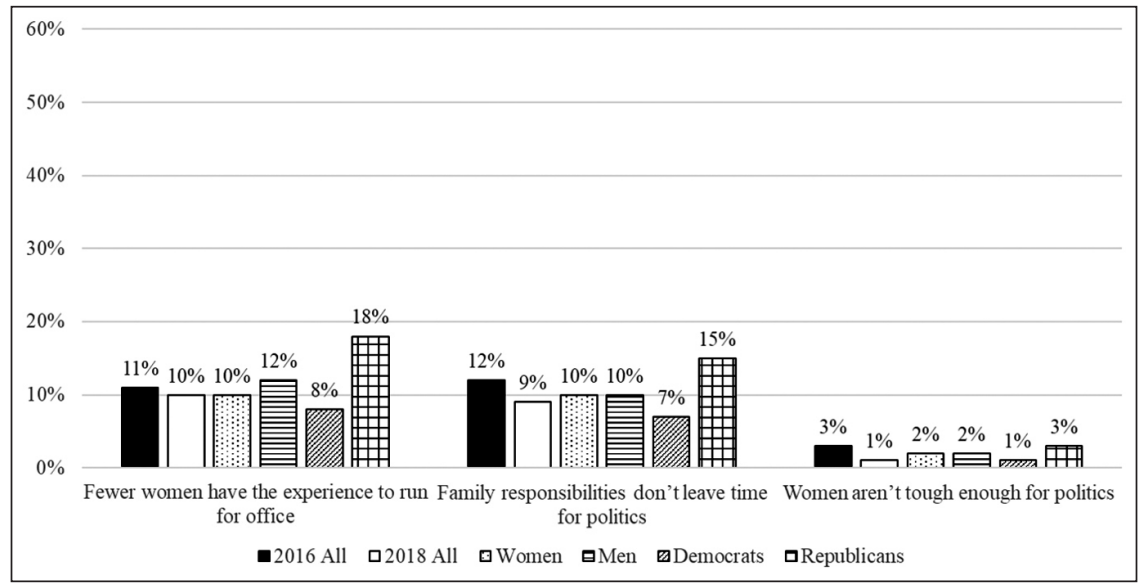

Figure 4. Reasons Why More Women Do Not Hold Elected Office in the United States Overall, and by Gender and Party Identification. (Source: Authors.)

identification is the dominant factor affecting how people understand levels of women's underrepresentation in American electoral politics. Democrats are more likely than Republicans to select system-level reasons shown in Figure 3 , suggesting that women receive less support from party leaders and face discriminatory barriers. Republicans, in contrast, are more likely than Democrats to select the three reasons shown in Figure 4 identifying factors related to individuals (what Dolan and Hansen call supply-level variables [2018]), such as family status and career paths. 
We do not simply want to rely on the descriptive data, however, so we ran six logistic regressions where the dependent variable in each is coded as one if the respondent chose the listed reason. ${ }^{8}$ Again, our primary variables of interest are party identification and gender, but we also controlled for age and race. ${ }^{9}$ Table 6 shows the results of each regression.

When examining the multivariate results, we see that party identification holds up as a significant predictor of all reasons offered by respondents. After controlling for party identification, only two reasons showed a significant gender effect; women were more likely than were men to say that women are held to higher standards and that women get less support from party leaders. Finally, since the questions about women's underrepresentation in politics were included in both the 2016 and 2018 exit polls, we are able to examine year effects. Notably, we find that respondents in 2018 were more likely than respondents in 2016 to say that women get less support from party leaders, but they were less likely to say that women aren't tough enough for politics.

\begin{tabular}{|c|c|c|c|c|c|c|}
\hline & $\begin{array}{l}\text { Higher } \\
\text { Standards }\end{array}$ & $\begin{array}{l}\text { Americans } \\
\text { Aren't } \\
\text { Ready }\end{array}$ & $\begin{array}{l}\text { Less } \\
\text { Support }\end{array}$ & $\begin{array}{l}\text { Less } \\
\text { Experience }\end{array}$ & $\begin{array}{l}\text { Family } \\
\text { Responsibilities }\end{array}$ & $\begin{array}{l}\text { Aren't } \\
\text { Tough } \\
\text { Enough }\end{array}$ \\
\hline Party ID & $\begin{array}{l}-0.957^{* * *} \\
(0.084)\end{array}$ & $\begin{array}{l}-0.551^{* * *} \\
(0.064)\end{array}$ & $\begin{array}{l}-0.210^{* *} \\
(0.063)\end{array}$ & $\begin{array}{l}0.510^{* * *} \\
(0.093)\end{array}$ & $\begin{array}{l}0.423^{* * *} \\
(0.096)\end{array}$ & $\begin{array}{c}0.485^{*} \\
(0.230)\end{array}$ \\
\hline Women & $\begin{array}{l}0.523^{* * *} \\
(0.115)\end{array}$ & $\begin{array}{c}0.112 \\
(0.101)\end{array}$ & $\begin{array}{l}0.274^{* *} \\
(0.100)\end{array}$ & $\begin{array}{l}-0.129 \\
(0.156)\end{array}$ & $\begin{array}{c}0.056 \\
(0.161) \\
\end{array}$ & $\begin{array}{l}-0.117 \\
(0.368)\end{array}$ \\
\hline Age & $\begin{array}{c}0.060 \\
(0.053)\end{array}$ & $\begin{array}{l}0.141^{* *} \\
(0.048)\end{array}$ & $\begin{array}{l}-0.149 * * \\
(0.047)\end{array}$ & $\begin{array}{c}0.091 \\
(0.075)\end{array}$ & $\begin{array}{c}0.110 \\
(0.077)\end{array}$ & $\begin{array}{l}-0.000 \\
(0.182)\end{array}$ \\
\hline White & $\begin{array}{c}0.170 \\
(0.149)\end{array}$ & $\begin{array}{l}-0.038 \\
(0.134)\end{array}$ & $\begin{array}{l}-0.084 \\
(0.133)\end{array}$ & $\begin{array}{c}0.199 \\
(0.229)\end{array}$ & $\begin{array}{c}0.344 \\
(0.246)\end{array}$ & $\begin{array}{c}0.076 \\
(0.561)\end{array}$ \\
\hline 2018 & $\begin{array}{c}0.013 \\
(0.126) \\
\end{array}$ & $\begin{array}{c}0.232^{*} \\
(0.109) \\
\end{array}$ & $\begin{array}{l}0.329 * * \\
(0.108)\end{array}$ & $\begin{array}{c}0.242 \\
(0.166) \\
\end{array}$ & $\begin{array}{c}0.044 \\
(0.168) \\
\end{array}$ & $\begin{array}{c}-0.742 \\
(0.394)\end{array}$ \\
\hline Constant & $\begin{array}{c}0.035 \\
(0.253)\end{array}$ & $\begin{array}{c}0.166 \\
(0.219)\end{array}$ & $\begin{array}{c}0.080 \\
(0.218)\end{array}$ & $\begin{array}{l}-3.531^{* * *} \\
(0.364)\end{array}$ & $\begin{array}{l}-3.579 * * * \\
(0.381)\end{array}$ & $\begin{array}{l}-4.607 * * * \\
(0.849)\end{array}$ \\
\hline$R^{2}$ & 0.096 & 0.044 & 0.024 & 0.031 & 0.025 & 0.039 \\
\hline$N$ & 1,728 & 1,728 & 1,728 & 1,728 & 1,725 & 1,726 \\
\hline $\begin{array}{l}\text { Dependent } \\
\text { Logistic reg } \\
{ }^{*} p<.05 \text {; }\end{array}$ & $\begin{array}{l}\text { variable is binar } \\
\text { ession coeffici } \\
p<.01 ;{ }^{* * *} p<\end{array}$ & $\begin{array}{l}\text {, coded } 1 \text { if re } \\
\text { nts are provide } \\
.001\end{array}$ & $\begin{array}{l}\text { pondent selec } \\
\text {, with standar }\end{array}$ & $\begin{array}{l}d \text { the reason ar } \\
\text { deviations in } p\end{array}$ & $\begin{array}{l}\text { d zero otherwise. } \\
\text { rentheses. }\end{array}$ & \\
\hline
\end{tabular}




\section{Discussion and Conclusion}

Taken collectively, the results of Pennsylvania exit polls conducted in 2016 and 2018 suggest that party, more than gender or women's issues per se, shaped voters' views and votes on Election Day. In this respect, what is most remarkable about the 2016 and 2018 elections might be how little changed. We find that gender mattered in both the 2016 and 2018 elections, but in different ways each year. In 2016 women were more likely than men to say they were Democrats, but there was no effect of gender above and beyond party identification when it came to vote choice in either the presidential or U.S. House elections. In 2018, however, we did not see any effect of gender on whether voters consider themselves Democrats or Republicans, but we saw gender play a role in vote choice, as women were more likely than men to report voting for Democratic Senate candidate Bob Casey as well as for U.S. House Democrats, regardless of candidate sex.

Even in electoral environments in which gender-related issues and identities were especially salient, as they were in 2016 and 2018, party affected how voters evaluated the actions of political candidates and considered the relevance of women's issues. In fact, in 2016 gender did not have any independent effect on how Pennsylvania voters explained their views on Trump's statements toward women, nor did gender have an independent effect on Pennsylvania voters' support for the Kavanaugh nomination. It did, however, affect their favorability toward the \#MeToo movement in 2018. To the extent that partisanship is the fundamental lens through which voters assess the relevance and appropriateness of candidates' behavior toward women, these findings may lend support to the notion that partisanship in the U.S. context increasingly functions as a form of expressive identity (Bankert, Huddy, and Rosema 2017; Huddy, Mason, and Aarøe 2015). These findings may also lend support to the concept of negative partisanship (Abramowitz and Webster 2016; Abramowitz and Webster 2017; Iyengar and Westwood 2015). Recent work on partisanship suggests that partisan cues increasingly influence decisions outside of politics, making partisanship not only a political divide, but a social divide as well (Iyengar and Westwood 2015). Partisan identification was the primary lens through which voters-both men and women-evaluated the relevance and saliency of Trump's comments toward women and the Kavanaugh nomination. Even if voters in Lehigh, Cumberland, and Allegheny Counties had reservations about Trump's comments or about the context surrounding the Kavanaugh hearings, Democrats were far more likely to say that it made a difference to their vote-and, given the strength of partisan attachments, it is highly likely that these voters would 
have voted against Trump (or any Republican) and for a 2018 Democratic candidate anyway.

At the same time that we find ongoing support for the centrality of partisan attachments, gender does seem to matter in the ways that voters understand and explain the underrepresentation of women in politics. Female respondents to our exit poll believe that electoral politics is not a level playing field for women, and these findings are independent of the effects of party. Female respondents were more likely to suggest that female candidates for office are held to higher standards than men and receive less support from party leaders. Moreover, when compared to voters in 2016, all voters in 2018including men and women-were more likely to say that women's underrepresentation is partially explained by the fact that women receive less support from party leaders. The notion that female candidates receive less support from party leaders has generated some empirical support in studies of Republican women's electoral candidacies and career paths (e.g., Rogers 2016; King and Matland 2003) and may itself partially reflect the ways in which gender stereotypes interact with party (perhaps leaving Republican women in a more difficult electoral situation, as Sanbonmatsu and Dolan [2009] point out).

We also suspect that 2018 was unique in two ways that likely shaped voters' perceptions of the electoral environment: first, the 2018 midterms followed closely on the heels of the defeat of the first major-party female presidential nominee; and second, the 2018 Year of the Woman elections featured women running as women, more than one-half of whom campaigned on women's issues, including structural gender-based discrimination. In this context, it is not especially surprising that survey respondents in 2018 were more likely than those in 2016 to say that many Americans weren't ready to elect women to political offices. Finally, in 2018, with historically high numbers of women running for office, voters were less likely to believe that women aren't tough enough for politics.

While our findings suggest that female respondents to our exit poll clearly perceive gender and gender discrimination to be relevant to women's electoral success, we also find that party has an independent effect on issues related to women's representation. Republicans and Democrats who responded to our exit poll offer divergent explanations for women's underrepresentation in politics. Republicans pointed to family responsibilities, women's lack of experience, and women's lack of toughness; Democrats were more likely to look to unequal standards, voters' sexist voting behavior, and lackluster support for women from party leaders. Put differently, Republicans emphasize candidatecentered explanations while Democrats emphasize systemic, institutional, or 
discriminatory explanations. ${ }^{10}$ Although we do not have empirical support from our exit poll, we suspect that this partisan divergence could be indicative of ideological sorting, with Republicans increasingly identified and aligned with traditional family values and Democrats aligned with progressive policy issues, including increasing opportunities for women in previously maledominated domains.

\section{NOTES}

1. There has been a surge of recent research on the role of sexism in shaping political behavior and electoral outcomes in recent elections. See Cassese and Holman (2019); Paul and Smith (2008); Ratliff et al. (2019); Schaffner, MacWilliams, and Nteta (2018); Streb et al. (2008); and Valentino, Wayne, and Oceno (2018).

2. See https://sarahniebler.com/data/ for complete survey questionnaires and toplines by county for 2016 and 2018 .

3. Weights were calculated separately by county, meaning that voters who completed surveys in Allegheny County were weighted to the vote totals of that county, those in Cumberland County were weighted to the vote totals of that county, and respondents in Lehigh County were weighted to the vote totals of that county. Survey weights of respondents who indicated they did not vote in the presidential election remained at 1.0, and all other weights were adjusted slightly so that the total number of respondents remained the same. As mentioned, our student interviewers spoke to a larger percentage of Clinton voters than Trump voters, so respondents who voted for Trump were weighted up while respondents who voted for Clinton were weighted down.

4. The independent variables are coded as follows: PartyID $(1=$ Democrat; $2=$ Independent; and 3 = Republican); Women (coded as 1 if yes); Age $(1=18-29$ years old; $2=$ $30-49$ years old; $3=50-64$ years old; and $4=65+$ years old); Education $(1=$ Less than high school; 2 = High school graduate; 3 = Some college or technical school; $4=4$-year college graduate; $5=$ Graduate or professional degree).

5. A gender affinity effect could also be present if large numbers of Democratic men broke with their party to support Trump in the 2016 election. We did not find that to be the case, however. In fact, running the same multivariate model as in Table 3, column 1, but replacing "GOP women" with "Democratic men" we find Democratic men also to be more likely to support Clinton than would be expected based on either their party or gender alone. We think this is due to the fact that such a high percentage of men identify as Republicans and therefore the overall expected level of support for Clinton among men is low. Complete results of this analysis are available upon request.

6. They were not, however, "secret Democrats" based on their responses to issue questions that were included in the survey. Republicans were less likely than Democrats to support increased gun regulations and were more likely than Democrats to say that the United States and other countries were doing enough to combat climate change. Interestingly, however, in our sample there were no differences between Democrats and Republicans with respect to their levels of approval for the job Donald Trump is doing as president.

7. Of the eight women who ran for Congress in 2018 from Pennsylvania, only one, Pearl Kim, ran as a Republican; she ran against another female candidate, Democrat Mary Gay Scanlon, in the 5th Congressional District. The 5th Congressional District 
covers Delaware County as well as small portions of Montgomery and Philadelphia Counties.

8. Many exit poll respondents offered additional reasons by selecting "other" and writing-in an open-ended response. In both 2016 and 2018, men were more likely than women to select "other" and to offer factors such as "don't run enough," "don't have an interest in running," "more women need to run," "sexism," "need the right candidate," "misogyny and its influences," and "incompetent electorate."

9. We also ran versions of these models that considered the knowledge question as an independent variable predicting the reasons respondents believe women are underrepresented in politics, but it was only asked in 2018. In these models, controlling for the same variables above, we found that voters' accurate knowledge about the absence of women from Pennsylvania in the House was only significantly related to the view that women lack the necessary experience for political office. In that model, voters who correctly answered " 0 " were more likely to say that women lack necessary experience for political office. Although limited, this finding is consistent with Dolan and Hansen (2018), who find that people with higher levels of political knowledge are less likely to attribute women's underrepresentation to discrimination or systemic causes.

10. A related finding about the views and beliefs of Republican and Democratic party activists found that Republicans and Democrats hold varying views on the existence of structural discrimination, with Republicans largely dismissing sex discrimination as holding women back, and Democrats viewing it as an ongoing problem (see Strolovitch, Wong, and Proctor 2017).

\section{REFERENCES}

Abramowitz, Alan. 2012. The Polarized Public: Why American Government Is So Dysfunctional. New York: Pearson.

Abramowitz, Alan, and Steven Webster. 2016. "The Rise of Negative Partisanship and the Nationalization of U.S. Elections in the 21st Century." Electoral Studies 41 (March): $12-22$.

- 2017. “Negative Partisanship' Explains Everything.” Politico, September/ October. Available at https://www.politico.com/magazine/story/2017/09/05/negative -partisanship-explains-everything-215534.

Bankert, Alexa, Leonie Huddy, and Martin Rosema. 2017. "Measuring Partisanship as a Social Identity in Multi-Party Systems." Political Behavior 39 (March): 103-132.

Berry, Marie E., and Erica Chenoweth. 2018. "Who Made the Women's March?" In The Resistance: The Dawn of the Anti-Trump Resistance Movement, eds. David S. Meyer and Sidney Tarrow. New York: Oxford University Press, 75-89.

Brians, Craig Leonard. 2005. "Women for Women? Gender and Party Bias in Voting for Female Candidates.” American Politics Research 33 (May): 357-375.

Campbell, David E., and Christina Wolbrecht. 2006. "See Jane Run: Women Politicians as Role Models for Adolescents.” Journal of Politics 68 (May): 233-247.

Cassese, Erin C., and Tiffany D. Barnes. 2019. "Reconciling Sexism and Women's Support for Republican Candidates: A Look at Gender, Class, and Whiteness in the 2012 and 2016 Presidential Races.” Political Behavior 41 (September): 677-700.

Cassese, Erin C., and Mirya R. Holman. 2019. "Playing the Woman Card: Ambivalent Sexism in the 2016 US Presidential Race.” Political Psychology 40 (February): 55-74. 
Chozick, Amy, and Jonathan Martin. 2015. “Clinton '16 Would Give Gender More of a Role than Clinton '08 Did.” New York Times, February 24. Available at https://www .nytimes.com/2015/02/25/us/politics/to-break-highest-glass-ceiling-clinton-gives -nod-to-gender.html.

CNN. 2012. "President: Full Results, Exit Polls." Available at http://www.cnn.com/election /2012/results/race/president/\#. Accessed April 4, 2018.

—. 2016. "Exit Polls." Available at https://edition.cnn.com/election/2016/results/exit -polls. Accessed April 4, 2018.

- 2018. "Exit Polls: National.” Available at https://www.cnn.com/election/2018/exit -polls. Accessed January 21, 2019.

Cohn, Nate. 2018. "For a Change, Democrats Seem Set to Equal or Exceed Republicans in Turnout" New York Times, October 19. Available at https://www.nytimes .com/2018/10/19/upshot/midterms-democrats-turnout-enthusiasm.html.

Dolan, Julie. 2004. "Gender Equity: Illusion or Reality for Women in the Federal Executive Service.” Public Administration Review 64 (May): 299-308.

Dolan, Kathleen. 1998. "Voting for Women in the 'Year of the Woman." American Journal of Political Science 42 (January): 272-293.

- 2004. Voting for Women: How the Public Evaluates Women Candidates. Boulder, CO: Westview Press.

_. 2014. "Gender Stereotypes, Candidate Evaluations, and Voting for Women Candidates: What Really Matters?” Political Research Quarterly 67 (March): 96-107.

Dolan, Kathleen, and Michael Hansen. 2018. "Blaming Women or Blaming the System? Public Perceptions of Women's Underrepresentation in Elected Office.” Political Research Quarterly 71 (September): 668-680.

Frasure-Yokley, Lorrie. 2018. "Choosing the Velvet Glove: Women Voters, Ambivalent Sexism, and Vote Choice in 2016." Journal of Race, Ethnicity, and Politics 3 (March): $3-25$.

Hayes, Danny. 2011. "When Gender and Party Collide: Stereotyping in Candidate Trait Attribution.” Politics \& Gender 7 (June): 133-165.

Hayes, Danny, and Jennifer Lawless. 2016. Women on the Run: Gender, Media, and Political Campaigns in a Polarized Era. Cambridge, MA: Cambridge University Press.

Huddy, Leonie, Lilliana Mason, and Lene Aarøe. 2015. "Expressive Partisanship: Campaign Involvement, Political Emotion, and Partisan Identity." American Political Science Review 109 (February): 1-17.

Iyengar, Shanto, and Sean J. Westwood. 2015. "Fear and Loathing across Party Lines: New Evidence on Group Polarization.” American Journal of Political Science 59 (July): 690-707.

Jacobson, Gary C. 2006. “The Polls': Polarized Opinion in the States: Partisan Differences in Approval Ratings of Governors, Senators, and George W. Bush.” Presidential Studies Quarterly 36 (4): 732-757.

Kapur, Shail, and John McCormick. 2018. "Kavanaugh Battle Expands Historic Gender Gap Before Election.” Bloomberg, October 1. Available at https://www.bloomberg .com/news/articles/2018-10-01/kavanaugh-battle-intensifies-historic-gender-gap -before-election.

King, David, and Richard Matland. 2003. "Sex and the Grand Old Party: An Experimental Investigation of the Effect of Candidate Sex on Support for a Republican Candidate." American Politics Research 31 (November): 595-612. 
Koch, Jeffrey. 1997. “Candidate Gender and Women's Psychological Engagement in Politics.” American Politics Research 25 (January): 118-133.

- 2000. "Do Citizens Apply Gender Stereotypes to Infer Candidates' Ideological Orientations?" Journal of Politics 62 (May): 414-429.

Lizotte, Mary-Kate. 2017. "Gender, Partisanship, and Issue Gaps.” Analyses of Social Issues and Public Policy 17 (December): 379-405.

Meyer, David S., and Sidney Tarrow, eds. 2018. The Resistance: The Dawn of the AntiTrump Resistance Movement. New York: Oxford University Press.

Nichols, Elizabeth Elianet. 2017. “For All the Dorothies': Motherhood as a Campaign Strategy in Hillary Clinton's 2016 Presidential Television Ads.” International Journal of Social Sciences, Humanities and Education 1 (2): 1-13.

Ondercin, Heather L. 2017. "Who Is Responsible for the Gender Gap? The Dynamics of Men's and Women's Democratic Macropartisanship, 1950-2012.” Political Research Quarterly 70 (December): 749-761.

Paul, David, and Jessi L. Smith. 2008. "Subtle Sexism? Examining Vote Preferences When Women Run Against Men for the Presidency." Journal of Women, Politics \& Policy 29 (4): 451-476.

Philpot, Tasha S. 2018. "Race, Gender, and the 2016 Presidential Election." PS: Political Science and Politics 51 (October): 755-761.

Presidential Gender Watch. 2017. "Finding Gender in Election 2016: Lessons from Presidential Gender Watch," Barbara Lee Family Foundation and Center for American Women and Politics. Available at http://presidentialgenderwatch.org/wp-content /uploads/2017/05/Finding-Gender-in-Election-2016.pdf.

Ratliff, Kate A., Liz Redford, John Conway, and Colin Tucker Smith. 2019. “Engendering Support: Hostile Sexism Predicts Voting for Donald Trump Over Hillary Clinton in the 2015 US Presidential Election." Group Processes \& Intergroup Relations 22 (June): 578-593.

Rogers, Kathleen. 2016. "The Women of the Pennsylvania General Assembly: Explaining Women's Representation in Pennsylvania Politics.” COMMONWEALTH: A Journal of Pennsylvania Politics and Policy 18 (2): 103-123.

Sanbonmatsu, Kira. 2002. "Gender Stereotypes and Vote Choice." American Journal of Political Science 46 (January): 20-34.

- 2003. "Gender-Related Political Knowledge and the Descriptive Representation of Women." Political Behavior 25 (December): 367-388.

Sanbonmatsu, Kira, and Kathleen Dolan. 2009. "Do Gender Stereotypes Transcend Party?” Political Research Quarterly 62 (September): 485-494.

Sapiro, Virginia, and Pamela Johnston Conover. 1997. "The Variable Gender Basis of Electoral Politics: Gender and Context in the 1992 US Election." British Journal of Political Science 27 (October): 497-523.

Schaffner, Brian F., Matthew MacWilliams, and Tatishe Nteta. 2018. "Understanding White Polarization in the 2016 Vote for President: The Sobering Role of Racism and Sexism." Political Science Quarterly 133 (March): 9-34.

Streb, Matthew J., Barbara Burrell, Brian Frederick, and Michael A. Genovese. 2008. "Social Desirability Effects and Support for a Female American President." Public Opinion Quarterly 72 (1): 76-89.

Strolovitch, Dara, Janelle Wong, and Andrew Proctor. 2017. "A Possessive Investment in White Heteropatriarchy? The 2016 Election and the Politics of Race, Gender, and Sexuality." Politics, Groups, and Identities 5 (2): 353-363. 
Tyson, Alec, and Shiva Maniam. 2016. "Behind Trump's Victory: Divisions by Race, Gender, Education.” PEW Research Center, November 9. Available at http://www .pewresearch.org/fact-tank/2016/11/09/behind-trumps-victory-divisions-by-race -gender-education/.

Valentino, Nicholas A., Carly Wayne, and Marzia Oceno. 2018. "Mobilizing Sexism: The Interaction of Emotion and Gender Attitudes in the 2016 US Presidential Election." Public Opinion Quarterly 82 (Special Issue): 799-821.

Sarah Niebler is an associate professor of political science at Dickinson College. Her research and teaching interests are in American politics, specifically political behavior, campaigns and elections, and public opinion. Sarah's scholarly work has been published in the American Journal of Political Science, Legislative Studies Quarterly, Political Communication, the Journal of Public Economics, the Journal of Elections, Public Opinion \& Parties, and American Politics Research. Additionally, her research and analysis has been featured on NPR's "Hidden Brain," and in The Hill and Roll Call, among others.

A. Lanethea Mathews-Schultz is professor and chair of political science at Muhlenberg College. Her research areas of interest include gender and American political development, civic engagement and political participation, and teaching and learning in political science. She is particularly interested in understanding how, when, and with what consequence relationships between citizens and political institutions change over time. Her publications have appeared in Political Research Quarterly, Social Science History, and Politics \& Gender. 